\section{Factors associated with time free of oral candidiasis in children living with HIV/AIDS, São Paulo, Brazil}

\author{
Fatores associados ao tempo livre de candidíase \\ oral em crianças vivendo com HIV/AIDS, \\ São Paulo, Brasil
}

\section{Factores asociados al tiempo libre y la candidiasis oral en niños que viven con VIH/SIDA, São Paulo, Brasil}

\begin{abstract}
In clinical practice, recurrence of thrush is common in children living with HIVIAIDS. The aim of this study was to determine the factors associated with time spent free of oral candidiasis using survival analysis for recurrent events. A retrospective cohort study was carried out with 287 children treated between 1985 and 2009 at a reference center in the city of São Paulo, Brazil. The Prentice, Williams and Peterson model for recurrent events was used for the investigation of factors associated with the time free of oral candidiasis. The following factors were associated with the time patients were free of oral candidiasis: moderate immunodepression $(H R=2.5$; $p=0.005)$, severe immunodepression (HR $=3.5$; $p<0.001)$, anemia (HR $=3.3 ; p<0.001)$, malnutrition ( $H R=2.6 ; p=0.004)$, hospitalization $(H R=2.2 ; p<0.001)$, monotherapy $(H R=0.5$; $p=0.006)$, dual therapy $(H R=0.3 ; p<0.001)$ and triple therapy/highly active antiretroviral therapy $(H R=0.1 ; p<0.001)$. The method analyzed in the present study proved useful for the investigation of recurrent events in patients living with HIVIAIDS.
\end{abstract}

Oral Candidiasis; HIV; Acquired Immunodeficiency Syndrome; Child; Survival Analysis
Thais Claudia Roma de Oliveira Konstantyner ${ }^{1}$ Aline Medeiros da Silva ${ }^{1}$ Luana Fiengo Tanaka 1 Heloísa Helena de Sousa Marques 2 Maria do Rosário Dias de Oliveira Latorre 1

\section{Resumo}

A recorrência da candidiase oral em crianças vivendo com HIVIAIDS é um acontecimento muito comum na prática clínica. O objetivo foi verificar os fatores associados ao tempo livre de candidíase oral, utilizando técnica de análise de sobrevida para eventos recorrentes. Estudo de coorte retrospectivo com 287 crianças, atendidas entre 1985 e 2009, em um serviço de saúde de São Paulo, Brasil. Foi utilizado o modelo marginal para eventos recorrentes de Prentice, Williams e Peterson para investigação dos fatores associados ao tempo livre de candidíase oral. Imunodepressão moderada $(H R=2,5 ; p=0,005)$ ou grave (HR=3,5; $p<0,001)$, anemia $(H R=3,3$; $p<0,001)$, desnutrição $(H R=2,6 ; p=0,004) e$ internação $(H R=2,2 ; p<0,001)$, monoterapia $(H R=0,5 ; p=0,006)$, terapia dupla $(H R=0,3$; $p<0,001)$ e terapia tripla/HAART $(H R=0,1$; $p<0,001)$ foram associados ao tempo livre de candidiase oral. A metodologia apresentada neste artigo pode ser bastante útil em pesquisas na área de HIVIAIDS, quando pretende-se estudar eventos com comportamento de recorrência.

Candidíase Bucal; HIV; Síndrome de Imunodeficiência Adquirida; Criança; Análise de Sobrevida 


\section{Introduction}

Persistent oral candidiasis (thrush) is the most frequent fungal condition among children living with human immunodeficiency virus/acquired immunodeficiency syndrome (HIV/AIDS) ${ }^{1}$. On the systemic level, this population is prone to the development of thrush due to the immunodeficiency caused by the harmful action of HIV on CD4+ T lymphocytes. Locally, an increase in the permeability of the epithelium and change in humoral immunity (IgA) of the oral mucosa stemming from the action of HIV facilitate infection by Candida 2 . Other factors commonly found in children living with HIV/AIDS, such as anemia, hospitalization, antiretroviral drugs and broadspectrum antibiotics, have also been implicated in the pathological mechanism of thrush 3,4 .

Persistent oral candidiasis is considered an important condition in the context of HIV/AIDS, as it affects quality of life and is an indicator of the progression of HIV infection 5,6,7,8,9. Consequently, a large amount of information has been published on the incidence of thrush and associated factors in periods prior to and following the advent of highly active antiretroviral therapy (HAART) using a single episode of thrush per individual as the unit of analysis 10,11,12. However, the recurrence of this condition is a very common event in clinical practice, as children living with HIV/AIDS often experience numerous episodes throughout their lives. Thus, the question arises as to whether the study of factors associated with the occurrence of thrush should consider only a single episode or multiple episodes throughout patient follow-up.

Few studies have employed survival analysis techniques developed for recurrent events, such as marginal models, in the investigation of this condition $13,14,15,16,17$. Thus, the aim of the present study was to determine factors associated with the time spent free of oral candidiasis in children living with HIV/AIDS using survival analysis for recurrent events.

\section{Methods}

A retrospective cohort study was carried out with children treated at a reference center for the treatment of AIDS in the city of São Paulo, Brazil. Data from medical charts were collected by a team of healthcare professionals using a previously tested, standardized chart.

The physicians at the reference center were trained to diagnose persistent oral candidiasis through: (i) a microscopic examination of a sample of the oral mucosa with characteristic findings; or (ii) a macroscopic examination of removable white plaques on erythematous tissue, following the recommendations of the Brazilian Ministry of Health 18.

The study population was made up of patients with a laboratory confirmation of HIV infection contracted through vertical transmission and less than 13 years of age at the time of admission to the health center. Patients in follow up for less than 90 days were excluded from the study. Children admitted to the health center between January 1, 1985 and October 1, 2009 were included and followed up until December 31, 2009 (end of the study). Different criteria for the definition of HIV infection and clinical conditions were used during the long follow-up period of the cohort, according to year of diagnosis 18,19,20,21.

The initial population was made up of 452 children, 325 of whom met the inclusion criteria. However, 38 were excluded for having a followup period of less than 90 days. Thus, the final sample was made up of 287 children.

A descriptive analysis (absolute and relative frequency distribution) of the cohort was first performed. The Kaplan-Meier product limit estimator 22 was then used to estimate the cumulative probability curves for the time between admission to the study and the emergence of oral candidiasis in relation to the independent variables (time of HIV diagnosis, gender, age, immune system impairment, viral load, anemia, malnutrition, hospitalization and antiretroviral regimen). The log-rank test was used for the comparison of the curves 23,24 . The $(-\ln (-\ln (\mathrm{S}(\mathrm{t}))))$ method in function of the follow-up time logarithm was used to determine the parallelism of the curves.

The Prentice, Williams and Peterson (PWP) marginal model for recurrent events was used to investigate factors associated with the time free of oral candidiasis. This model considers events in time and assumes that the basal risk of a new event is different from but dependent on the previous event 24,25 . The hazard ratio (HR) was estimated for each independent variable. The Wald test was used to test the hypothesis that $\mathrm{HR}=125$. The null hypothesis was rejected when the $\mathrm{p}$-value was $\leq 0.05$.

For the use of the PWP model, an event was considered to be the occurrence of an episode of oral candidiasis and it was defined that up to three episodes per individual could be counted. Censure occurred in four situations: (i) patients in follow up at the end of the study; (ii) those transferred to another health center; (iii) those who abandoned follow up; and (iv) those who died.

The 287 children were distributed among three risk strata. A particular number of obser- 
vations were entered in the database for each child based on the number of episodes of oral candidiasis: 198 children who did not develop oral candidiasis made up stratum 1 (each contributed one observation to the database); $44 \mathrm{ex}-$ hibited one episode of oral candidiasis and made up strata 1 and 2 (each contributed two observations to the database); 26 exhibited two episodes of oral candidiasis and made up strata 1, 2 and 3 (each contributed three observations to the database); and 19 exhibited three episodes of oral candidiasis and made up strata 1, 2 and 3 (each contributed three observations to the database). Thus, the cohort was formed by 421 observations among 287 children (Figure 1).

Time was the dependent variable and was defined based on the order of occurrence of events:

- 1 st time interval (stratum 1): period (in years) between the beginning of follow up at the reference center and the date of the first episode of oral candidiasis or censure;

- $2^{\text {nd }}$ time interval (stratum 2): period (in years) between the date of thefirst episodeand the date of the second episode of oral candidiasis or censure;
- 3 rd time interval (stratum 3): period (in years) between the date of the second episode and the date of the third episode of oral candidiasis or censure.

The forward stepwise method was employed in the multivariate modeling. For such, variables with a $p$-value $<0.20$ in the univariate analysis of the PWP model were selected. The variables that maintained statistical significance $(\mathrm{p} \leq 0.05)$ (immune system impairment, anemia, malnutrition, hospitalization and antiretroviral regimen) and those that statistically adjusted the parameters of the other variables (time of HIV diagnosis) remained in the final model. Proportionality of risk over time was determined using Schoenfeld's residual analysis, which employs a chi-square statistic with one degree of freedom based on the proportion of observed and expected survival 22 . All analyses were performed using the Stata program, version 11 (Stata Corp., College Station, USA).

This study received approval from the $\mathrm{Hu}$ man Research Ethics Committee of the School of Public Health, São Paulo University, Brazil (USP) under process number CEP/FSP n. 2033.

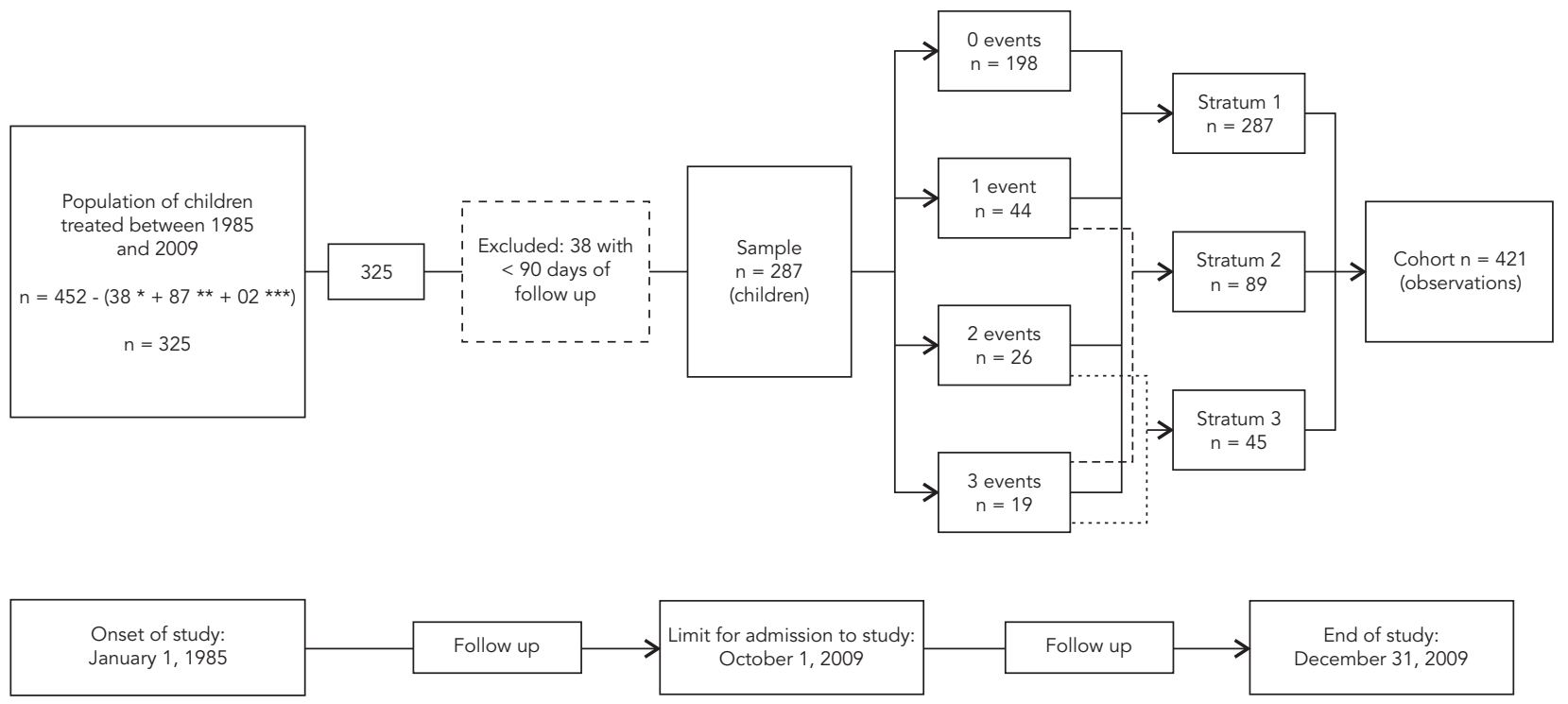

\footnotetext{
* Children without laboratory exams confirming HIV infection;

** Children who did not acquire HIV infection through vertical transmission;

*** Children aged $\geq 13$ years upon admission to healthcare center.
} 


\section{Results}

A total of 421 observations relating to 287 children with HIV infection between 1985 and 2009 were analyzed. Mean follow-up time was $6.8 \pm 5.0$ years (range: 0.3 to 17.8 years). Table 1 displays the distribution of observations according to the demographic, clinical and treatment characteristics of the children. The majority $(67.5 \%)$ received a laboratory diagnosis of HIV prior to the advent of HAART; $51.3 \%$ were female and nearly half $(47.5 \%)$ were aged between one and five at onset of follow up. More than $70 \%$ exhibited immune system impairment and nearly $100 \%$ had a detectable plasma viral load during the follow-up period for oral candidiasis. Up to three months before the appearance of oral candidiasis, $8.1 \%$ of exhibited anemia, $6.2 \%$ were diagnosed with malnutrition and $31.3 \%$ had at least one hospitalization. Regarding antiretroviral treatment, HAART $(43.4 \%)$ was the most recent regimen both prior to the appearance of oral candidiasis as well as among those patients with no diagnosis of this condition.

Figure 2 shows the cumulated probability of time free of oral candidiasis according to the independent variables. Significant differences among the curves were found for the following variables: period of HIV diagnosis $(\mathrm{p}<0.001)$, immune system impairment $(\mathrm{p}<0.001)$, anemia $(\mathrm{p}<0.001)$, malnutrition ( $\mathrm{p}<0.001)$, hospitalization $(\mathrm{p}<0.001)$ and antiretroviral regimen $(\mathrm{p}<0.001)$. The survival time free of oral candidiasis was greater among the children with a diagnosis of infection following the advent of HAART and those without anemia, malnutrition or hospitalization. In contrast, the survival time was reduced with the exacerbation of immune system impairment as well as with the reduction in the number of drugs in the antiretroviral regimen.

Table 2 displays the results of the analysis using the PWP model. In the univariate analysis, the following variables were associated with the time free of oral candidiasis: laboratory diagnosis of HIV prior to the advent of HAART ( $\mathrm{HR}=2.5$; $\mathrm{p}<0.001)$, severe immunodepression $(\mathrm{HR}=2.3$; $\mathrm{p}=0.001)$, anemia (HR $=5.7 ; \mathrm{p}<0.001)$, malnutrition $(\mathrm{HR}=6.3 ; \mathrm{p}<0.001)$ and hospitalization $(\mathrm{HR}=3.2 ; \mathrm{p}<0.001)$. Dual therapy $(\mathrm{HR}=0.3$; $\mathrm{p}<0.001)$ and triple therapy/HAART $(\mathrm{HR}=0.1$; $\mathrm{p}<0.001$ ) were protection factors against the manifestation of oral candidiasis.

Year of HIV diagnosis, immune system impairment, anemia, malnutrition, hospitalization and antiretroviral regimen were selected for multivariate modeling and 352 observations made up the final model. The following variables were independently associated with time free of oral candidiasis: moderate immunodepression (HR $=2.5 ; \mathrm{p}=0.005)$, severe immunodepression $(\mathrm{HR}=3.5 ; \mathrm{p}<0.001)$, anemia $(\mathrm{HR}=3.3 ; \mathrm{p}<0.001)$, malnutrition $(\mathrm{HR}=2.6 ; \mathrm{p}=0.004)$ and hospitalization $(\mathrm{HR}=2.2 ; \mathrm{p}<0.001)$. Monotherapy $(\mathrm{HR}=0.5$; $\mathrm{p}=0.006)$, dual therapy $(\mathrm{HR}=0.3 ; \mathrm{p}<0.001)$ and triple therapy/HAART (HR $=0.1 ; \mathrm{p}<0.001$ ) were independent protection factors. Time of the laboratory diagnosis of HIV infection remained in the final model for adjustments, but was nonsignificant. The risk proportionality of the model was determined and this presupposition was fulfilled $\left(\chi^{2}=9.84 ; \mathrm{p}=0.363\right)$.

\section{Discussion}

Candidiasis has considerable clinical significance in the prognosis of HIV infection and as an indicator of the non-effectiveness of antiretroviral treatment 26,27 . While some authors state that the use of statistical methods that do not consider the recurrence of episodes of thrush could lead to errors in the estimate of risks 14,28,29,30, there is debate regarding whether the analysis of a single episode may correspond equally to the joint analysis of multiple episodes in some situations 31 .

In the present study, the investigation of factors associated with the time patients are free of oral candidiasis revealed the following independent predictors of the disease: moderate to severe immunodepression, anemia, malnutrition and hospitalization. Moreover, the use of antiretroviral therapy (monotherapy, dual therapy or triple therapy/HAART) proved to be an independent protection factor.

Survival free of disease was closely linked to the degree of immunodepression, as risk increased with the exacerbation of immune system impairment. This association has been described in previous cohorts of children throughout the world 32,33,34. However, researchers state that defenses against Candida may be compromised by HIV even before the drop in the levels of CD4+ T lymphocytes 35,36 , which may explain the appearance of thrush in individuals with HIV whose defense cell counts are within the range of normality.

In the present study, anemia was a predictor of oral candidiasis, as the time free of this disease was greater in children without anemia. Different clinical presentations of oral candidiasis, especially the mucocutaneous and angular forms, have previously been associated with anemia 37 . Besides iron deficiency, which is the main cause of childhood anemia, other nutritional disorders have been implicated in the occurrence of oral 
Table 1

Distribution of observations * according to demographic, clinical, laboratory and treatment characteristics; reference center in São Paulo, Brazil, 1985-2009.

\begin{tabular}{|c|c|c|}
\hline Variable & $\mathrm{n}$ & $\%$ \\
\hline \multicolumn{3}{|l|}{ Period of HIV diagnosis } \\
\hline Pre-HAART (1985-1997) & 284 & 67.5 \\
\hline Post-HAART (1998-2009) & 137 & 32.5 \\
\hline Total & 421 & 100.0 \\
\hline \multicolumn{3}{|l|}{ Gender } \\
\hline Female & 216 & 51.3 \\
\hline Male & 205 & 48.7 \\
\hline Total & 421 & 100.0 \\
\hline \multicolumn{3}{|c|}{ Age at onset of follow up (years) } \\
\hline$<1$ & 144 & 34.2 \\
\hline $1-5$ & 200 & 47.5 \\
\hline$\geq 6$ & 77 & 18.3 \\
\hline Total & 421 & 100.0 \\
\hline \multicolumn{3}{|l|}{ Immune system impairment ** } \\
\hline Absence & 88 & 24.0 \\
\hline Moderate & 125 & 34.2 \\
\hline Severe & 153 & 41.8 \\
\hline Total & 366 & 100.0 \\
\hline \multicolumn{3}{|l|}{ Plasma viral load $* \star[n=248]$} \\
\hline Undetectable & 1 & 0.4 \\
\hline Detectable & 247 & 99.6 \\
\hline Total & 248 & 100.0 \\
\hline \multicolumn{3}{|l|}{ Anemia *** } \\
\hline No & 387 & 91.9 \\
\hline Yes & 34 & 8.1 \\
\hline \multicolumn{3}{|l|}{ 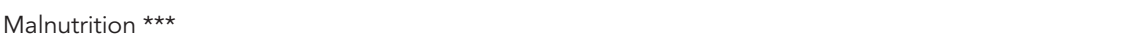 } \\
\hline No & 395 & 93.8 \\
\hline Yes & 26 & 6.2 \\
\hline \multicolumn{3}{|l|}{ 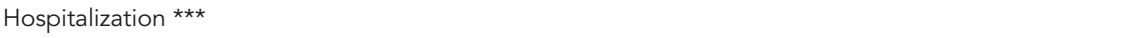 } \\
\hline No & 279 & 68.7 \\
\hline Yes & 127 & 31.3 \\
\hline Total & 406 & 100.0 \\
\hline \multicolumn{3}{|l|}{ Antiretroviral regimen \# } \\
\hline No treatment & 89 & 21.2 \\
\hline Monotherapy & 66 & 15.8 \\
\hline Dual therapy & 82 & 19.6 \\
\hline Triple therapy/HAART & 182 & 43.4 \\
\hline Total & 419 & 100.0 \\
\hline
\end{tabular}

HAART: highly active antiretroviral therapy.

* Relating to 287 children;

** Up to three months before or three months after appearance of oral candidiasis in cases of occurrence of disease or at end of study for cases in which disease did not occur;

*** Up to three months before appearance of oral candidiasis in cases of occurrence of disease or throughout study for cases in which disease did not occur;

\# Most recent regimen before appearance of oral candidiasis in cases of occurrence of disease or last regimen received throughout study for cases in which disease did not occur. 
2a) Period of HIV diagnosis

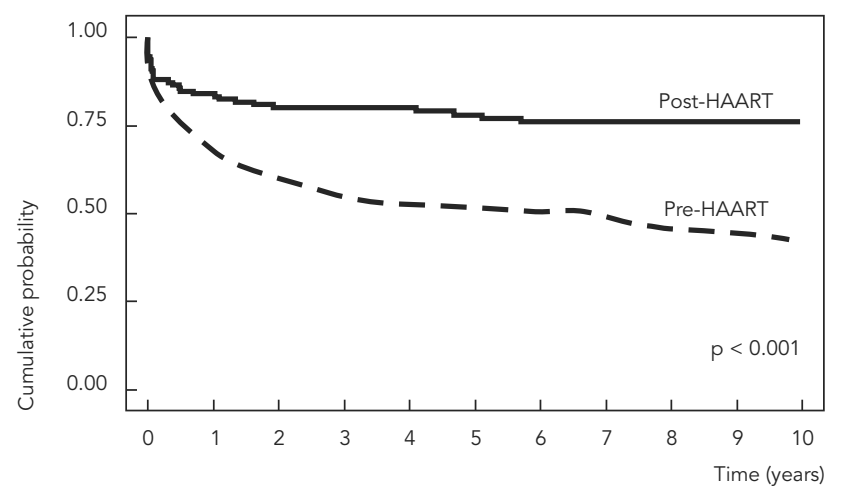

2c) Age

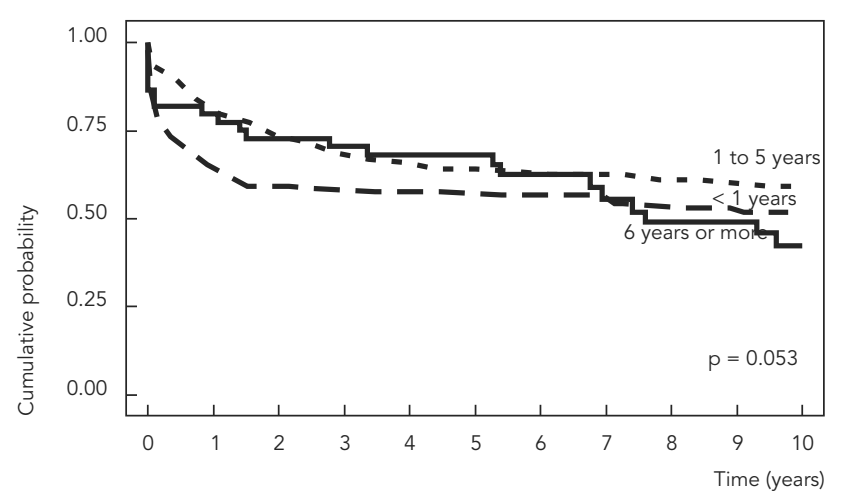

2b) Immune system impairment

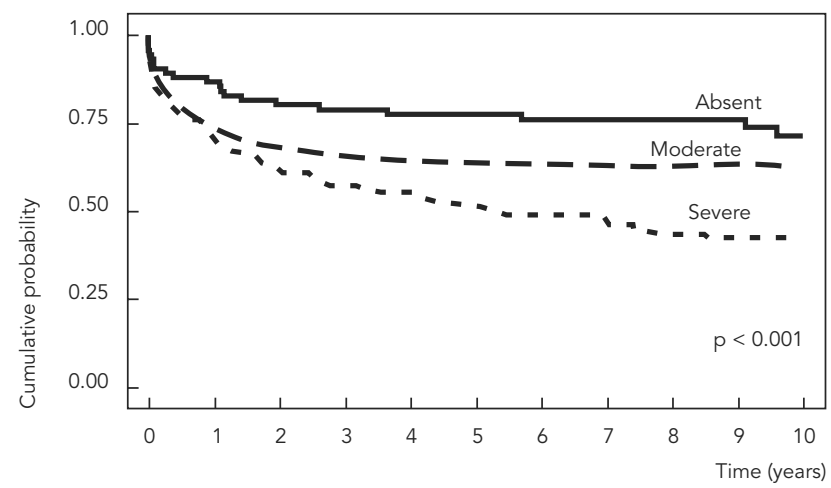

2d) Gender

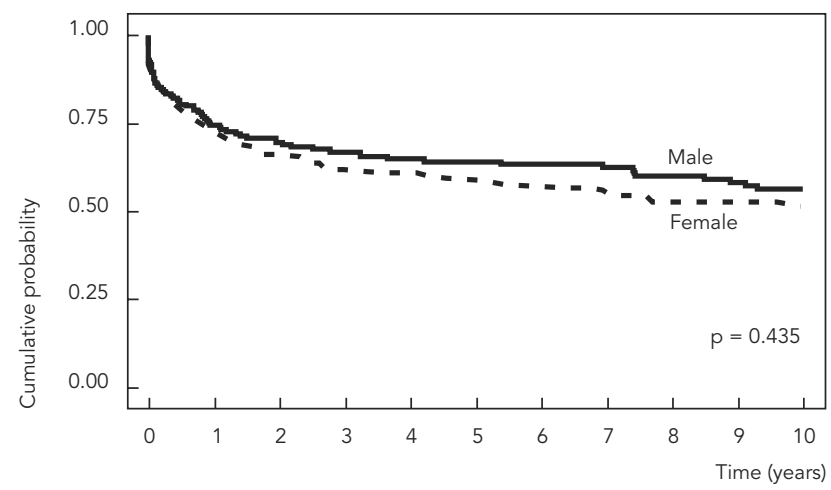

candidiasis among children living with HIV/ AIDS. In the present study, the time patients were free of oral candidiasis was significantly shorter among malnourished children. Previous studies have also found malnutrition to be a systemic risk factor for the development of oral candidiasis 38,39 .

Hospitalization was investigated as a proxy variable of serious diseases to which children infected with HIV are subject. Hospitalization is a frequent, critical process among such children due to the exacerbation of the clinical situation or the social status of the child 40,41 . In the present study, a significant association was found with hospitalization (regardless of the determinant cause), as survival time free of oral candidiasis was greater in children who had not been hospitalized.

The present study also demonstrated the beneficial effect of antiretroviral drugs, especially HAART, in the prevention of oral candidiasis. This finding has been previously reported for Brazilian children 42,43 . Moreover, the time patients were free of oral candidiasis increased with the addition of new drugs to the antiretroviral regimen. These results are in agreement with findings reported in previous studies, which defend the hypothesis that antiretroviral drugs not only reestablish systemic immunological competence, but also improve the immune response of the oral mucosa against the fungus 44,45 . This may explain situations in which the resolution of 


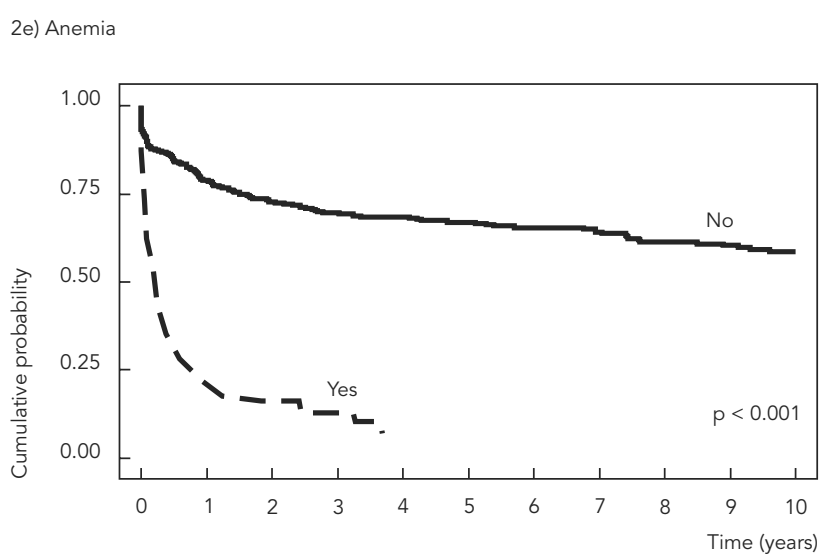

2g) Hospitalization

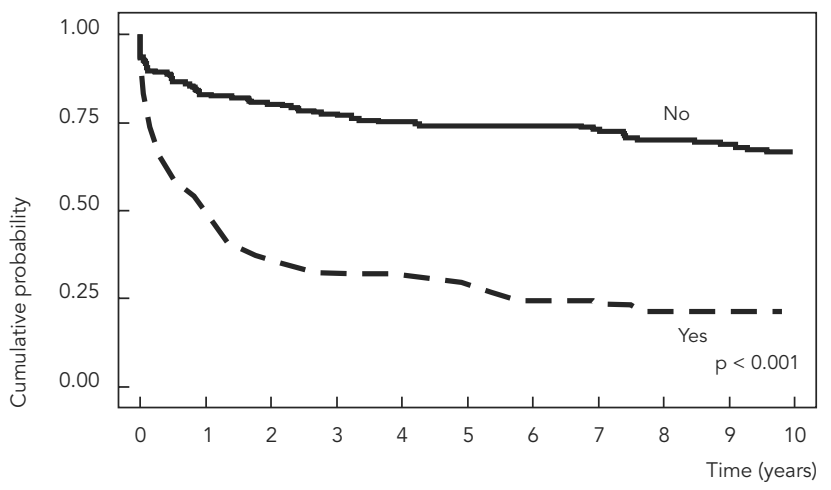

2f) Malnutrition

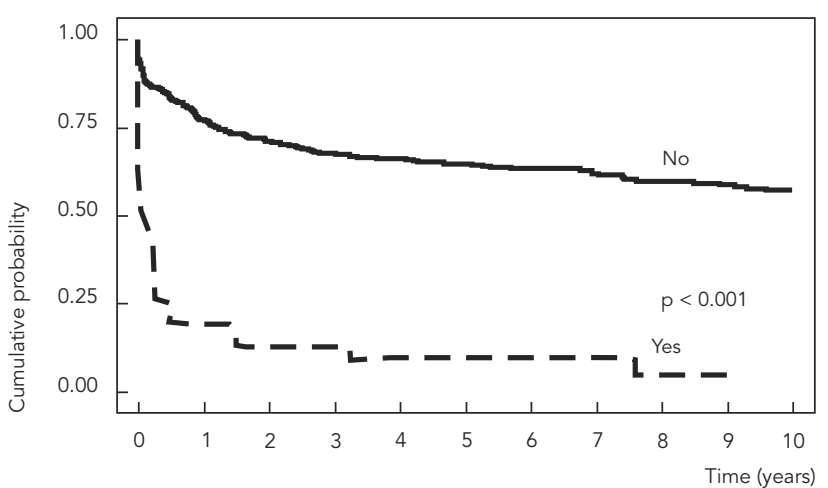

2h) Antirretroviral regimen

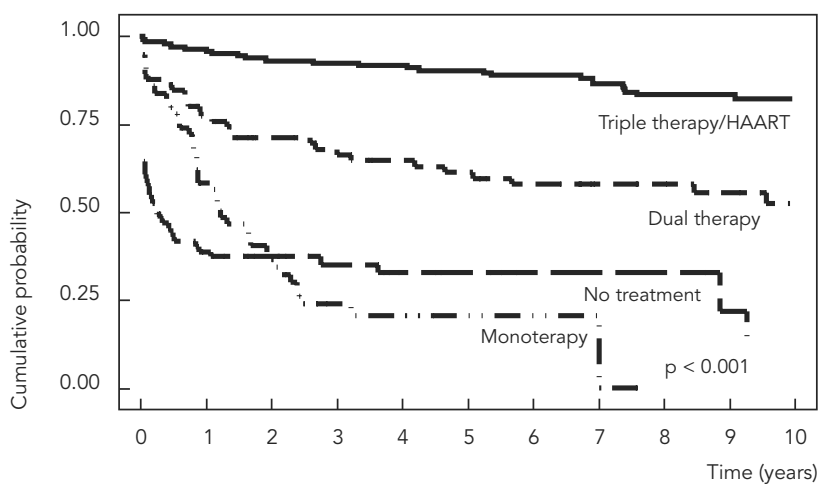

HAART: highly active antiretroviral therapy.

oral candidiasis precedes the reestablishment of normal CD4+ T lymphocyte counts 46 .

No associations were found between survival time free of oral candidiasis and the gender or age of children living with HIV/AIDS. These results are in agreement with findings reported in a cohort of American children 33.

Due to the nearly $100 \%$ prevalence rate of a detectable viral load, it was not possible to determine the association between this variable and the risk of developing oral candidiasis. However, high viral loads have been associated with compromised oral health in the pediatric population living with HIV/AIDS 36,47,48. Moreover, while no analysis was performed of associations between the prior use of antibiotics and/or corticoids and the appearance of oral candidiasis in the present study, these groups of medications have been described as risk factors for this condition due to the fact that they alter the local flora and create a favorable environment for the fungus 37 .

The present study has limitations that should be considered. Due to the cohort design, the reference for the comparisons was the availability of different treatment regimens in different times of the year and with different degrees of adherence. However, this strategy is employed and defended by a number of authors 49,50 . Different criteria for the definition of cases were used during the long follow-up period of the cohort, with an increasingly earlier diagnosis and onset of treatment/prophylaxis over the years. Moreover, the source document for the data collection was the child's medical chart, which was not always filled out satisfactorily for the purposes of the present study. To minimize possible bias, care was taken 
Univariate and multivariate analyses of factors associated with time free of oral candidiasis in children infected by HIV; reference center in São Paulo, Brazil, 1985-2009.

\begin{tabular}{|c|c|c|c|c|c|c|}
\hline \multirow[t]{2}{*}{ Variable } & \multicolumn{2}{|c|}{ Oral candidiasis } & \multirow[t]{2}{*}{ HR } & \multirow[t]{2}{*}{$p$-value } & \multirow[t]{2}{*}{ Adjusted HR } & \multirow[t]{2}{*}{$\mathrm{p}$-value } \\
\hline & $\mathbf{n}$ & $\%$ & & & & \\
\hline \multicolumn{7}{|l|}{ Period of HIV diagnosis } \\
\hline Pre-HAART (1985-1997) & 125 & 44.0 & 1.0 & $<0.001$ & 1.0 & 0.093 \\
\hline Post-HAART (1998-2009) & 28 & 20.4 & 2.5 & & 1.6 & \\
\hline \multicolumn{7}{|l|}{ Gender } \\
\hline Female & 80 & 37.0 & 1.0 & 0.974 & - & - \\
\hline Male & 73 & 35.6 & 1.0 & & - & \\
\hline \multicolumn{7}{|c|}{ Age at onset of follow up (years) } \\
\hline$\geq 6$ & 28 & 36.4 & 1.0 & & - & - \\
\hline $1-5$ & 65 & 32.5 & 0.8 & 0.353 & - & \\
\hline$<1$ & 60 & 41.7 & 1.3 & 0.280 & - & \\
\hline \multicolumn{7}{|l|}{ Immune system impairment * } \\
\hline Absent & 22 & 25.0 & 1.0 & & 1.0 & \\
\hline Moderate & 40 & 32.0 & 1.5 & 0.121 & 2.5 & 0.005 \\
\hline Severe & 68 & 44.4 & 2.3 & 0.001 & 3.5 & $<0.001$ \\
\hline \multicolumn{7}{|l|}{ Anemia ** } \\
\hline No & 126 & 32.6 & 1.0 & $<0.001$ & 1.0 & $<0.001$ \\
\hline Yes & 27 & 79.4 & 5.7 & & 3.3 & \\
\hline \multicolumn{7}{|l|}{ Malnutrition ** } \\
\hline No & 135 & 34.2 & 1.0 & $<0.001$ & 1.0 & 0.004 \\
\hline Yes & 18 & 69.2 & 6.3 & & 2.6 & \\
\hline \multicolumn{7}{|l|}{ Hospitalization ** } \\
\hline No & 76 & 27.2 & 1.0 & $<0.001$ & 1.0 & $<0.001$ \\
\hline Yes & 72 & 56.7 & 3.2 & & 2.2 & \\
\hline \multicolumn{7}{|l|}{ 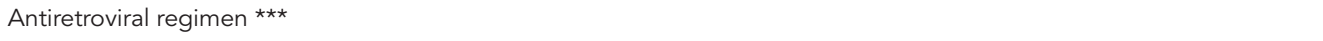 } \\
\hline No treatment & 50 & 56.2 & 1.0 & & 1.0 & \\
\hline Monotherapy & 40 & 60.6 & 0.9 & 0.670 & 0.5 & 0.006 \\
\hline Dual therapy & 28 & 34.1 & 0.3 & $<0.001$ & 0.3 & $<0.001$ \\
\hline Triple therapy/HAART & 35 & 19.2 & 0.1 & $<0.001$ & 0.1 & $<0.001$ \\
\hline
\end{tabular}

HAART: highly active antiretroviral therapy; HR: hazard ratio.

* Up to three months before or three months after appearance of oral candidiasis in cases of occurrence of disease or at end of study for cases in which disease did not occur;

** Up to three months before appearance of oral candidiasis in cases of occurrence of disease or throughout study for cases in which disease did not occur;

$\star \star \star$ Most recent regimen before appearance of oral candidiasis in cases of occurrence of disease or last regimen received throughout study for cases in which disease did not occur.

to ensure the standardization of the data collection from the charts and a review of all questionnaires. Additionally, the inclusion criteria (acquisition of HIV infection through vertical transmission and age zero to 13 years) minimized difficulties in the comparison of the children analyzed with regard to clinical-epidemiological data and strengthened the homogeneity of the sample.

It should be stressed that the choice of the PWP marginal model is considered adequate for modeling recurrent events and the variables of interest are known and available for the analysis of factors associated with the time patients are free of oral candidiasis 30,51. Despite the sophistication of current statistical packages, which enable the complete execution of this type of modeling in a matter of minutes, the organization and analysis of the databank were performed with caution, since the statistical theory behind this type of model is complex. 
In conclusion, the present study identified immunodepression, anemia, malnutrition, hospitalization and antiretroviral therapy as factors associated with the time patients are free of oral candidiasis in a population of children living with
HIV/AIDS in the city of Sao Paulo, Brazil. Moreover, the method presented in this article can be useful for the investigation of recurrent events in studies addressing HIV/AIDS.

\section{Resumen}

La repetición de candidiasis oral en los niños que viven con VIH/SIDA es muy común en la práctica clínica. El objetivo fue verificar los factores asociados al tiempo libre y la candidiasis oral, usando la técnica de análisis de supervivencia para eventos recurrentes. Se realizó un estudio de cohorte retrospectiva con 287 niños que visitaron entre 1985 y 2009 un servicio de salud de São Paulo, Brasil. Se usó el modelo marginal para eventos recurrentes de Prentice, Williams y Peterson, con el fin de investigar los factores asociados. Moderada inmunodepresión ( $H R=2,5 ; p=0,005)$ o grave $(H R=3,5$; $p<0,001)$, anemia (HR $=3,3 ; p<0,001)$, desnutrición (HR $=2,6 ; p=0,004)$ y hospitalización (HR =2,2; $p<0,001)$, monoterapia (HR $=0,5 ; p=0,006)$, terapia dual $(H R=0,3 ; p<0,001)$ y triple terapia/TARGA ( $H R=0,1 ; p<0,001)$ se asociaron al tiempo libre y la candidiasis oral. La metodología presentada en este artículo puede ser útil para la investigación en el área de VIH/SIDA, cuando se pretenda estudiar el comportamiento de la repetición del evento.

Candidiasis Bucal; HIV; Síndrome de Inmunodeficiencia; Niño; Análisis de Supervivencia

\section{Contributors}

T. C. R. O. Konstantyner participated in the design and planning, data collection and analysis and interpretation, elaboration of the draft, and approval of the final version of the article. A. M. Silva participated in the design and planning, data collection, critical review of the content, and approval of the final version of the article. L. F. Tanaka participated in the design and planning, data collection, critical review of the content, and approval of the final version of the article. H. H. S. Marques participated in the design and planning, critical review of the content, and approval of the final version of the article. M. R. D. O. Latorre participated in the design and planning, critical review of the content, and approval of the final version of the article. 


\section{References}

1. Centers for Disease Control and Prevention. Guidelines for prevention and treatment of opportunistic infection among HIV-exposed and HIV-infected children. MMWR Recomm Rep 2009; 58:1-166.

2. Challacombe SJ, Naglik JR. The effects of HIV infection on oral mucosa immunity. Adv Dental Res 2006;19:29-35.

3. Naidoo S, Chikte U. Oro-facial manifestations in paediatric HIV: a comparative study of institutionalized and hospital outpatients. Oral Dis 2004; 10:13-8.

4. Candiani TMS, Pinto J, Cardoso CAA, Carvalho IR, Dias ACM, Carneiro M, et al. Impact of highly active antiretroviral therapy (HAART) on the incidence of opportunistic infections, hospitalizations and mortality among children and adolescents living with HIV/AIDS in Belo Horizonte, Minas Gerais State, Brazil. Cad Saúde Pública 2007; 23 Suppl 3:S414-23.

5. Greenspan JS. Sentinels and signposts: the epidemiology and significance of the oral manifestations of HIV disease. Oral Dis 1997; 3 Suppl 1:13-7.

6. Margiotta V, Campisi G, Mancuso S, Accurso V, Abbadessa V. HIV infection: oral lesions, CD4+ cell count and viral load in an Italian study population. J Oral Pathol Med 1999; 28:173-7.

7. Patton LL, McKaig RG, Eron Jr. JJ, Lawrence HP, Strauss RP. Oral hairy leukoplakia and oral candidiasis as predictors of HIV viral load. AIDS 1999; 13:2174-6.

8. Ramírez-Amador V, Esquivel-Pedraza L, SierraMadero J, Soto-Ramirez L, González-Ramírez I, Anaya-Saavedra G, et al. Oral clinical markers and viral load in a prospective cohort of Mexican HIVinfected patients. AIDS 2001; 15:1910-1.

9. Gaitán-Cepeda LA, Domínguez-Sánchez A, PavíaRuz N, Muñoz-Hernández R, Verdugo-Díaz R, Valles-Medina AM, et al. Oral lesions in HIV+/AIDS adolescents perinatally infected undergoing HAART. Med Oral Patol Oral Cir Bucal 2010; 15:e545-550.

10. Powderly WG, Finkelstein D, Feinberg J, Frame P, He W, van der Horst C, et al. A randomized trial comparing fluconazole with clotrimazole troches for the prevention of fungal infections in patients with advanced Human Immunodeficiency Virus infection. N Engl J Med 1995; 332:700-5.

11. Nittayananta W, Chanowanna N, Sripatanakul S, Winn T. Risk factors associated with oral lesions in HIV infected heterosexual people and intravenous drug users in Thailand. J Oral Pathol Med 2001; 30:224-30.

12. Pomarico L, Cerqueira DF, Soares RMA, Souza IP, Castro GFA, Socransky S, et al. Associations among the use of highly active antiretroviral therapy, oral candidiasis, oral Candida species and salivary immunoglobulin A in HIV-infected children. Oral Sur Oral Medi Med Oral Pathol Oral Radiol Endod 2009; 108:203-10.

13. Finkelstein DM, Schoenfeld DA, Stamenovic E. Analysis of multiple failure time data from an Aids clinical trial. Stat Med 1997; 16:951-61.
14. Donaldson MG, Sobolev B, Cook WL, Janssen PA, Khan KM. Analysis of recurrent events: a systematic review of randomised controlled trials of interventions to prevent falls. Age Ageing 2009; 38:151-5.

15. Prentice RL, Williams BJ, Peterson AV. On the regression analysis of the multivariate failure time data. Biometrika 1981; 68:373-9.

16. Andersen PK, Gill RD. Cox's regression model for counting processes: a large sample study (and commentary). Ann Stat 1982;4:1100-24.

17. Wei LJ, Lin DJ, Weisseld L. Regression analysis of multivariate incomplete failure time data. J Am Stat Assoc 1989; 84:1065-73.

18. Coordenação Nacional de DST e AIDS, Secretaria de Políticas de Saúde, Ministério da Saúde. Critérios de definição de casos de AIDS em adultos e crianças, Brasil, 2004. Brasília: Ministério da Saúde; 2004.

19. Centers for Disease Control and Prevention. Classification system for human immunodeficiency virus (HIV) infection in children under 13 years of age. MMWR Morb Mortal Wkly Rep 1987; 36:225-36.

20. Centers for Disease Control and Prevention. Revised classification system of human immunodeficiency virus infection in children less than 13 years of age. MMWR Morb Mortal Wkly Rep 1994; 43:1-10.

21. Coordenação Nacional de DST e AIDS, Secretaria de Políticas de Saúde, Ministério da Saúde. Revisão da definição nacional de caso de AIDS em indivíduos menores de 13 anos, para fins de vigilância epidemiológica. Brasília: Ministério da Saúde; 2000.

22. Kleinbaum DG. Survival analysis: a self-learning text. New York: Springer; 1995.

23. Bustamante-Teixeira MT, Faerstein E, Latorre MR. Técnicas de análise de sobrevida. Cad Saúde Pública 2002; 18:579-94.

24. Carvalho MS, Andreozzi VL, Codeço CT. Análise de sobrevida - teoria e aplicações em saúde. Rio de Janeiro: Editora Fiocruz; 2005.

25. Therneau TM, Grambsch PM. Modeling survidal data: extendig the Cox model. 2nd Ed. New York: Springer; 2000.

26. Chidzonga MM, Mwale M, Malvin K, Martin JN, Greenspan JS, Shiboski CH. Oral candidiasis as a marker of HIV disease progression among Zimbabwean women. J Acquir Immune Defic Syndr 2008; 47:579-84

27. Alves FBT, Czlusniak GD, Dal'Maso AMS, Shimizu $\mathrm{KH}$, Verri MA. Lesões estomatológicas em crianças HIV positivas e suas implicações clínicas. Arq Odontol 2009; 45:191-8.

28. Li GH, Lagakos SW. Use of the Wei-Lin-Weissfeld method for the analysis of a recurring and a terminating event. Stat Med 1997; 16:925-40.

29. Mahe C, Chevret S. Estimation of the treatment effect in a clinical trial when recurrent events define the endpoint. Stat Med 1999; 18:1821-9. 
30. Castro MSM, Carvalho MS, Travassos C. Factors associated with readmission to a general hospital in Brazil. Cad Saúde Pública 2005; 21:1186-200.

31. Tai BC, De Stavola BL, de Gruttola V, Gebski V, Machin D. First-event or marginal estimation of cause-specific hazards for analysing correlated multivariate failure-time data? Stat Med 2008; 27:922-36.

32. Chiou CC, Groll AH, Gonzalez CE, Callender D, Venzon D, Pizzo PA, et al. Esophageal candidiasis in pediatric acquired immunodeficiency syndrome: clinical manifestation and risk factors. Pediatr Infect Dis J 2000; 19:729-34.

33. Ylitalo N, Brogly S, Hughes MD, Nachman S, Dankner W, Van Dyke R, et al. Risk factors for opportunistic illnesses in children with human immunodeficiency virus in the era of highly active antiretroviral therapy. Arch Pediatr Adolesc Med 2006; 160:778-87.

34. Fonseca R, Cardoso AS, Pomarico I. Frequency of oral manifestations in children infected with human immunodeficiency virus. Quintessence Int 2000; 31:419-22.

35. Repentigny L, Lewandowski D, Jolicoeur P. Immunopathogenesis of oropharyngeal candidiasis in human immunodeficiency virus infection. Clin Microbiol Rev 2004; 17:729-59.

36. Leao JC, Ribeiro CM, Carvalho AA, Frezzini C, Porter S. Oral complications of HIV disease. Clinics (São Paulo) 2009; 64:459-70.

37. Farah CS, Ashman RB, Challacombe SJ. Oral candidosis. Clin Dermatol 2000; 18:553-63.

38. Akapan A, Morgan R. Oral candidiasis. Postgrad Med J 2002; 78:455-9.

39. Gaitán-Cepeda LA, Sánchez-Vargas LO, Pavia-Ruz N, Muñoz-Hernández R, Villegas-Ham J, CaballosSalobreña A. Candida bucal en niños mexicanos con VIH/sida, desnutrición o marginación social. Rev Panam Salud Pública 2012; 31:48-53.

40. Marques HHS, Couttolenc BF, Latorre MRDO, Aquino MZ, Aveiro MIG, Pluciennik AMA. Costs of care provided in a university hospital for children exposed to or infected with the HIV/AIDS. Cad Saúde Pública 2007; 23 Suppl 3:S402-13.

41. Vijayan T, Benin AL, Wagner K, Romano S, Andiman WA. We never thought this would happen: transitioning care of adolescents with perinatally acquired HIV infection from pediatrics to internal medicine. AIDS Care 2009; 21:1222-9.
42. Cerqueira DF, Portela MB, Pomarico L, de Araújo Soares RM, de Souza IP, Castro GF. Oral Candida colonization and its relation with predisposing factors in HIV-infected children and their uninfected siblings in Brazil: the era of highly active antiretroviral therapy. J Oral Pathol Med 2010; 39:188-94.

43. Domaneschi C, Massarente DB, de Freitas RS, de Sousa Marques HH, Paula CR, Migliari DA, et al. Oral colonization by Candida species in AIDS pediatric patients. Oral Dis 2011; 17:393-8.

44. Cassone A, Tacconelli E, De Bernardis F, Tumbarello M, Torosantucci A, Chiani P, et al. Antiretroviral therapy with protease inhibitors has an early, immune reconstitution-independent beneficial effect on Candida virulence and oral candidiasis in human immunodeficiency virus-infected subjects. J Infect Dis 2002; 185:188-95.

45. Rwenyonyi CM, Kutesa A, Muwazi L, Okullo I, Kasangaki A, Kekitinwa A. Oral manifestation in HIV/ AIDS infected children. Eur J Dent 2011; 5:291-8.

46. Bektić J, Lell CP, Fuchs A, Stoiber H, Speth C, LassFlörl C, et al. HIV protease inhibitors attenuate adherence of Candida albicans to epithelial cells in vitro. FEMS Immunol Med Microbiol 2001; 31:65-71.

47. Mercante DE, Leigh JE, Lilly EA, McNulty K, Fidel Jr. PL. Assessment of the Association between HIV viral load and CD4 cell count on the occurrence of oropharyngeal candidiasis in HIV-infected patients. J Acquir Immune Defic Syndr 2006; 42:578-83.

48. Massarente DB, Domaneschi C, Marques HH, Andrade SB, Goursand D, Antunes JL. Oral healthrelated quality of life of paediatric patients with AIDS. BMC Oral Health 2011; 11:2-7.

49. Mocroft A, Gill MJ, Davidson W, Phillips AN. Are there gender differences in starting protease inhibitors, HAART, and disease progression despite equal access to care? J Acquir Immune Defic Syndr 2000; 24:475-82.

50. Ewings FM, Bhaskaran K, McLean K, Hawkins D, Fisher M, Fidler S, et al. Survival following HIV infection of a cohort followed up from seroconversion in the UK. AIDS 2008; 22:89-95.

51. Cleves M. How do I analysis of multiple failuretime data using Stata? Stata FAQ: analysis of multiple failure-time survival data. http://www.stata com/support/faqs/stat/stmfail.html (accessed on Jul/2009).

Submitted on 16/Feb/2013

Final version resdubmitted on 26/May/2013

Approved on 05/Jun/2013 